\title{
Synthesis and structural characterization of $\left(\mathrm{C}_{14} \mathrm{H}_{16} \mathrm{~N}_{2}\right)_{3}\left(\mathrm{C}_{14} \mathrm{H}_{17} \mathrm{~N}_{2}\right)_{2}\left[\beta-\mathrm{Mog}_{8} \mathrm{O}_{26}\right]$
}

\author{
IKRAM ZEBIRI $^{\mathrm{a}}$, SIHEM BOUFAS ${ }^{\mathrm{b}}$, SALIMA MOSBAH ${ }^{\mathrm{a}}$, LEÏLA BENCHARIF ${ }^{\mathrm{a}}$ and \\ MUSTAPHA BENCHARIF ${ }^{\mathrm{a}, *}$ \\ a Laboratoire de Chimie des Matériaux Constantine, Université Constantine 1, 25000 Constantine, Algérie \\ ${ }^{\text {b} F a c u l t e ́ ~ d e ~ T e c h n o l o g i e, ~ U n i v e r s i t e ́ ~} 20$ Août 1955, 21000 Skikda, Algérie \\ e-mail: m_bencharif@umc.edu.dz
}

MS received 19 April 2015; revised 8 July 2015; accepted 13 July 2015

\begin{abstract}
A novel polyoxomolybdate $\left(\mathrm{C}_{14} \mathrm{H}_{16} \mathrm{~N}_{2}\right)_{3}\left(\mathrm{C}_{14} \mathrm{H}_{17} \mathrm{~N}_{2}\right)_{2}\left[\beta-\mathrm{Mo}_{8} \mathrm{O}_{26}\right]$ (1) has been synthesized from hydrothermal reaction of tolidine and molybdenum trioxide in water and characterized by its IR and UV spectra, ${ }^{1} \mathrm{H}$ NMR, cyclic voltammetry and single crystal X-ray diffraction. Compound $\mathbf{1}$ crystallizes in the triclinic crystal system, space group $\mathrm{P} \overline{1}$, with the crystal cell parameters of $a=11.5360 \AA, b=11.6080 \AA, c=15.2520 \AA$, $\alpha=72.50^{\circ}, \beta=79.46^{\circ}, \gamma=86.91^{\circ}, V=1915.00 \AA^{3}$ and $Z=1$. The asymmetric unit of the crystal structure of $\left(\mathrm{C}_{14} \mathrm{H}_{16} \mathrm{~N}_{2}\right)_{3}\left(\mathrm{C}_{14} \mathrm{H}_{17} \mathrm{~N}_{2}\right)_{2}\left[\beta-\mathrm{Mo}_{8} \mathrm{O}_{26}\right]$ contains $\beta$-octamolybdate $\left[\beta-\mathrm{Mo}_{8} \mathrm{O}_{26}\right]^{4-}$ anions, two tolidine molecules and shows the presence of monoprotonated tolidine cations. One tolidine molecule and a $\beta-\mathrm{Mo}_{8} \mathrm{O}_{26}$ polyanions species lie across crystallographic inversion centres while the two tolidine molecules occupy general sites.
\end{abstract}

Keywords. $\quad \beta$-Octamolybdate; Crystal structure; Electronic properties.

\section{Introduction}

Polyoxometalates (POMs) have attracted considerable attention due to potential applications in a variety of fields, including catalysis, analytic chemistry, medicine and materials science. ${ }^{1-5}$ In particular, the chemistry of coordination compounds of polyoxomolybdates with organic ligands provides knowledge about the interactions of small organic molecules with polyoxometalates surfaces. ${ }^{6}$ Furthermore, it is noteworthy that an important field in the polyoxomolybdates is the strctural chemistry of the well-known polyoxomolybdate anion, $\left[\mathrm{Mo}_{8} \mathrm{O}_{26}\right]^{4-}$. An interesting aspect of octmolybdates is seen in varied structural patterns in the solid state and in their structural flexibility in soltion. ${ }^{7} \mathrm{Six}$ isomeric forms of octamolybdate $\left[\mathrm{Mo}_{8} \mathrm{O}_{26}\right]^{4-}$ have been prepared. ${ }^{8-13}$ The $\alpha$ - and $\beta$ forms have been crystallographically confirmed in several hybrid materials. ${ }^{14,15}$ The $\gamma$-isomer has been found in $\left[\left(\mathrm{CH}_{3}\right)_{3} \mathrm{~N}\left(\mathrm{CH}_{2}\right)_{6} \mathrm{~N}\left(\mathrm{CH}_{3}\right)_{3}\right]_{2}\left[\mathrm{Mo}_{8} \mathrm{O}_{26}\right] \cdot 2 \mathrm{H}_{2} \mathrm{O} .{ }^{12}$ The $\delta$ isomer in $\left[\left(\mathrm{RhCp}^{*}\right)_{2}\left(\mu-\mathrm{SCH}_{3}\right)_{3}\right]_{4}\left[\mathrm{Mo}_{8} \mathrm{O}_{26}\right] \cdot 2 \mathrm{CH}_{3} \mathrm{CN},{ }^{7}$ (2,4,6-tripyridyl triazine $)_{2}\left[\mathrm{Mo}_{8} \mathrm{O}_{26}\right] \cdot 2 \mathrm{H}_{2} \mathrm{O}^{16}$ and $[\{\mathrm{Cu}$ (4,4-bipy) $\left.\}_{4}\left(\mathrm{Mo}_{8} \mathrm{O}_{26}\right)\right]^{13}$ has also been recently characterized. More recently, the $\varepsilon$ and $\zeta$-isomers have been characterized in the products of hydrothermal reactions. ${ }^{13,17}$ The structures of the six octamolybdate isomers differ in the types of polyhedron that

\footnotetext{
*For correspondence
}

fuse to form the cluster and in the linkage between polyhedral, ${ }^{7-18}$ however, they are all composed of only two different molybdenum polyhedra. To the best of our knowledge, the octamolybdate isomers that contain $\mathrm{Mo}(\mathrm{VI})$ in three different types of coordination have not been observed hitherto.

These octamolybdate isomers are versatile inorganic building blocks for constructing new organicinorganic hybrid materials with desirable properties. ${ }^{19}$ In this paper, we report the hydrothermal synthesis and X-ray crystal structure determination of a new $\beta$ octamolybdate, $\left(\mathrm{C}_{14} \mathrm{H}_{16} \mathrm{~N}_{2}\right)_{3}\left(\mathrm{C}_{14} \mathrm{H}_{17} \mathrm{~N}_{2}\right)_{2} \quad \beta$ - $\left[\mathrm{Mo}_{8} \mathrm{O}_{26}\right]$ which has been characterized by IR and UV-Vis spectra, ${ }^{1} \mathrm{H}$ NMR, cyclic voltammetric data and electronic properties. The structure consists of alternating organic and inorganic layers; the inorganic layers are formed by $\left[\mathrm{Mo}_{8} \mathrm{O}_{26}\right]^{4-}$ anions and the organic layers are built of $\left(\mathrm{C}_{14} \mathrm{H}_{17} \mathrm{~N}_{2}\right)^{+}$cations and $\left(\mathrm{C}_{14} \mathrm{H}_{16} \mathrm{~N}_{2}\right)$ molecules.

\section{Experimental}

\subsection{Materials and methods}

Commercially available Molybdenum trioxide $\mathrm{MoO}_{3}$, tolidine $\mathrm{C}_{14} \mathrm{H}_{16} \mathrm{~N}_{2}$, lithium perchlorate $\mathrm{LiClO}_{4}$, diméthylformamide sulfoxide DMSO, were used without further purification. Hydrothermal synthesis has been carried out using a $23 \mathrm{~mL}$ Teflon-lined autoclave. IR 
spectra were obtained as KBr pellets on a FTIR-8201PC SHIMADZU spectrophotometer. ${ }^{1} \mathrm{H}$ NMR spectra were recorded on a Bruker Avance DPX $250(250 \mathrm{~Hz})$. UVVis spectra were recorded on a Jasco V-660 spectrophotometer. Cyclic voltammetry measurements were performed in a one-compartment cell with the use of a PGZ workstation at room temperature. The working and counter electrodes were platinum disk with a surface area of $1 \mathrm{~mm}^{2}$ and platinum wire, respectively. All potentials were referred to a saturated calomel electrode (SCE). The typical solutions in DMSO were $5.10^{-3}$ mol.L ${ }^{-1}$ in $\mathrm{LiClO}_{4}, 0.1 \mathrm{M}$. All solutions were deaerated by a dry nitrogen stream, maintained at a slight $\mathrm{N}_{2}$ overpressure during the experiments.

\subsection{Hydrothermal synthesis}

$\left(\mathrm{C}_{14} \mathrm{H}_{16} \mathrm{~N}_{2}\right)_{3}\left(\mathrm{C}_{14} \mathrm{H}_{17} \mathrm{~N}_{2}\right)_{2}\left[\mathrm{Mo}_{8} \mathrm{O}_{26}\right]$ (1) was synthesized from the reaction mixture of $\mathrm{C}_{14} \mathrm{H}_{16} \mathrm{~N}_{2}(0.212 \mathrm{~g}, 2$ $\mathrm{mmol})$ and $\mathrm{MoO}_{3}(0.144 \mathrm{~g}, 1 \mathrm{mmol})$ in $6 \mathrm{~mL}$ of distilled water. The resulting solution was adjusted to about $\mathrm{pH}$ 5-7 with $6 \mathrm{M} \mathrm{HCl}$. After stirring for $30 \mathrm{~min}$, the mixture was transferred to a $23 \mathrm{~mL}$ sealed Teflon-lined reactor and heated at $140^{\circ} \mathrm{C}$ for $24 \mathrm{~h}$. After cooling the autoclave to room temperature for $48 \mathrm{~h}$, yellow-green crystals obtained were filtered, washed several times with distilled water and dried in air.

\section{$2.3 X$-ray crystallographic study}

Single crystal of compound (1) with dimension $0.22 \mathrm{x}$ $0.15 \times 0.09 \mathrm{~mm}$ was carefully selected for single crystal X-ray diffraction analysis. Data collection was performed on a APEXII, Bruker-AXS diffractometer with Mo $K a$ monochromatic radiation $(\lambda=0.71073 \AA)$ at 150(2) K. Empirical absorption correction was applied. The structure was refined by the full matrix leastsquares method on $F^{2}$ using the SHELXL-97 crystallographic software package. ${ }^{20}$ Anisotropic thermal parameters were used to refine all non-hydrogen atoms.

The methyl $\mathrm{H}$ atoms and ammonium $\mathrm{H}$ atoms were constrained to an ideal geometry $(\mathrm{C}-\mathrm{H}=0.96 \AA$, $\mathrm{N}-$ $\mathrm{H}=0.91 \AA$ ) with $\mathrm{U}_{\text {iso }}(\mathrm{H})=1.5 \mathrm{U}_{\text {eq }}(\mathrm{C})$ and $\mathrm{U}_{\text {iso }}(\mathrm{H})$ $=1.5 \mathrm{U}_{\mathrm{eq}}(\mathrm{N})$, but were allowed to rotate freely about the $\mathrm{C}-\mathrm{C}$ and $\mathrm{C}-\mathrm{N}$ bonds. $\mathrm{H}$ atoms of amino groups were constrained to an ideal geometry $\mathrm{N}-\mathrm{H}=0.88$ $\AA$ with $\mathrm{U}_{\text {iso }}(\mathrm{H})=1.2 \mathrm{U}_{\mathrm{eq}}(\mathrm{C})$. All remaining $\mathrm{H}$ atoms were placed in geometrically idealized positions $(\mathrm{C}-\mathrm{H}$ $=0.95 \AA$ ) and constrained to ride on their parent atoms with $\mathrm{U}_{\text {iso }}(\mathrm{H})$ values of $1.2 \mathrm{U}_{\text {eq }}(\mathrm{C})$. Crystal data are listed in table 1.
Table 1. Crystal data and structure refinements for $\left(\mathrm{C}_{14} \mathrm{H}_{16} \mathrm{~N}_{2}\right)_{3}\left(\mathrm{C}_{14} \mathrm{H}_{17} \mathrm{~N}_{2}\right)_{2}\left[\mathrm{Mo}_{8} \mathrm{O}_{26}\right]$.

\begin{tabular}{ll}
\hline Molecule formula & $\mathrm{C}_{70} \mathrm{H}_{82} \mathrm{Mo}_{8} \mathrm{~N}_{10} \mathrm{O}_{26}$ \\
\hline Molecule weight & 2246.98 \\
Wavelength $(\AA)$ & 0.71073 \\
Crystal system & Triclinic \\
Space group & $\mathrm{P}-1$ \\
$\mathrm{a}(\AA)$ & $11.5453(15)$ \\
$\mathrm{b}(\AA)$ & $11.6342(15)$ \\
$\mathrm{c}(\AA)$ & $15.2755(19)$ \\
$\alpha(\mathrm{deg})$ & $72.375(5)$ \\
$\beta(\mathrm{deg})$ & $79.327(5)$ \\
$\gamma(\mathrm{deg})$ & $86.852(6)$ \\
$\mathrm{V}\left(\AA^{3}\right)$ & $1921.7(4)$ \\
$\mathrm{Z}$ & 1 \\
$\left.\mu(\mathrm{mm})^{-1}\right)$ & 1.348 \\
$\mathrm{~T}(\mathrm{~K})$ & 150 \\
Reflections measured & 27416 \\
Reflections independent & 8736 \\
Limiting indices & $-14 \leq \mathrm{h} \leq 14,-15 \leq \mathrm{k} \leq 15$, \\
& $-19 \leq \mathrm{l} \leq 13$ \\
Crystal size(mm) & $0.22 \times 0.15 \times 0.09$ \\
Diffractometer & APEXII, Brüker-AXS \\
\hline
\end{tabular}

\section{Results and Discussion}

\subsection{Crystal structure}

In the present work, the synthesis by the hydrothermal method of $\mathrm{MoO}_{3}$ and 3,3'-dimethyl-4,4'-diaminobiphenyl resulted in the compound $\left(\mathrm{C}_{14} \mathrm{H}_{16}\right.$ $\left.\mathrm{N}_{2}\right)_{3}\left(\mathrm{C}_{14} \mathrm{H}_{17} \mathrm{~N}_{2}\right)_{2}\left[\mathrm{Mo}_{8} \mathrm{O}_{26}\right]$. As shown in figure 1, the compound contains six subunits (in a 3:2:1 ratio), viz. $\left(\mathrm{C}_{14} \mathrm{H}_{16} \mathrm{~N}_{2}\right)$ molecules, a cationic group $\left(\mathrm{C}_{14} \mathrm{H}_{17} \mathrm{~N}_{2}\right)^{+}$ and its anionic counterpart, $\beta$-[ $\left[\mathrm{Mo}_{8} \mathrm{O}_{26}\right]^{4-}$ cluster. The octamolybdate anion and one tolidine molecule lie around an inversion center.

The structure of title compound 1 consists of $\beta$ $\mathrm{Mo}_{8} \mathrm{O}_{26}$ polyanions and organic cations. These anions are constituted by eight $\mathrm{MoO}_{6}$ octahedra sharing edges and corners. The octahedra have different Mo-O bonds, which can be classified as short terminal [1.69019(9)1.7219(9) $\AA$ ], intermediate length lying in the range

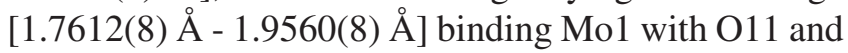
Mo1 with O4 and long bonds [1.9986(8)- 2.4754(8) $\AA$ ]. In the octamolybdate anion, there are three different types of $\mathrm{MoO}_{6}$ octahedra: (i) octahedra formed by atoms Mo1 and Mola, which, being closest to the centroid of the polyanion, are the least distorted; (ii) octahedra formed by atoms Mo2 and Mo2a, which are the most distorted since they are farthest from the centroid; and (iii) octahedra formed by atoms Mo3, Mo3a, Mo4 and Mo4a, which have an intermediate degree of distortion. 


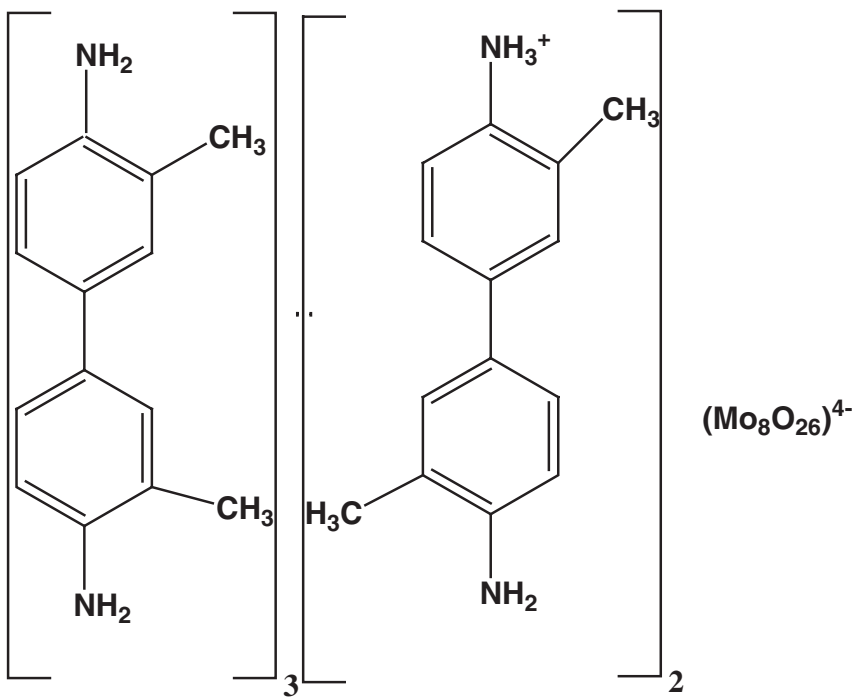

(a)

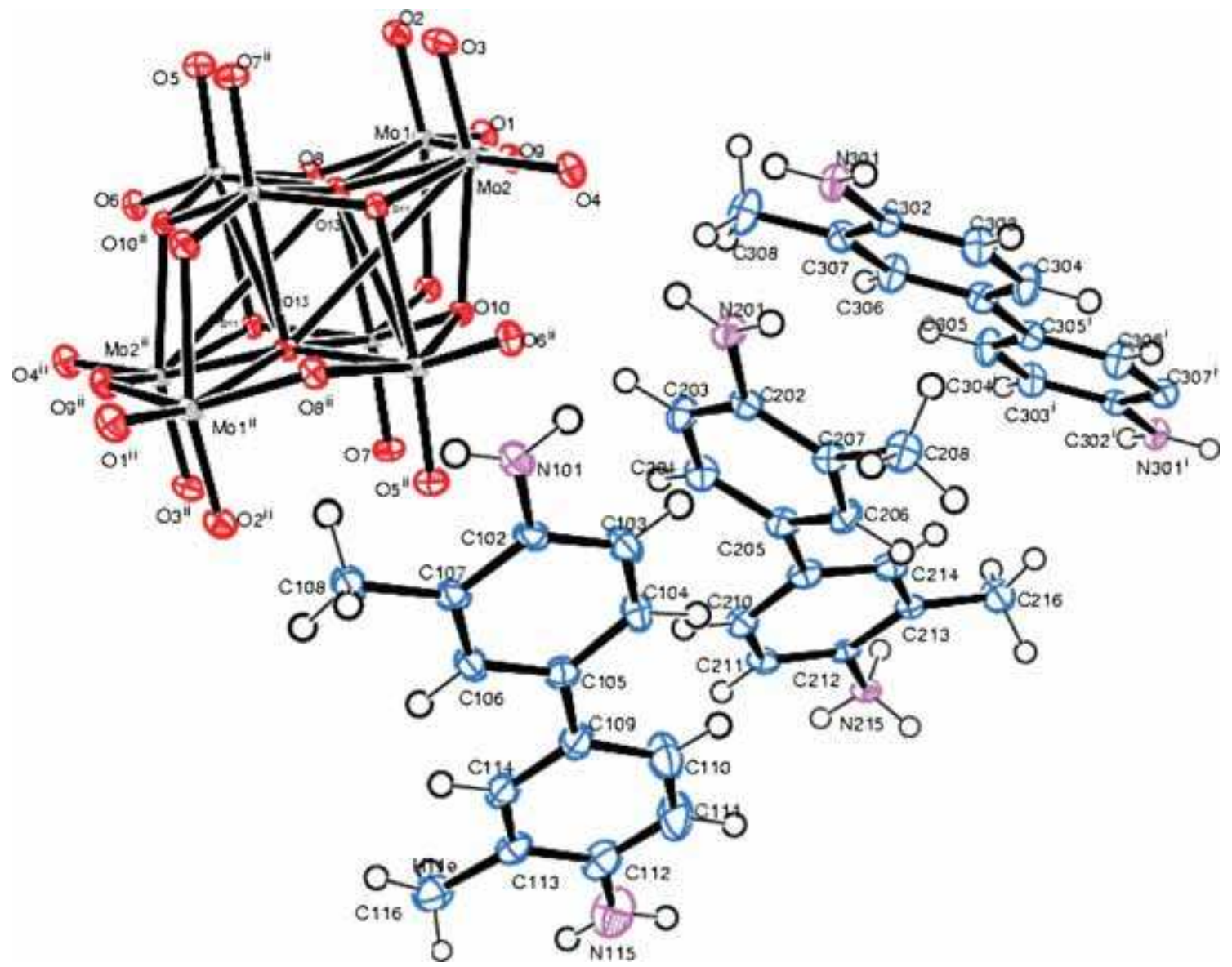

(b)

Figure 1. (a) A split view of the molecular structure of 1; (b) ORTEP drawing of compound 1 showing the labeling of atoms with thermal ellipsoids at $50 \%$ probability.

A striking structural feature is that the anions extend the linkage into a one-dimensional inorganic double chain-like structure via weak interactions: $\mathrm{O}-\mathrm{O} 2.926$

$\AA$ along the direction of $b$-axis (figure 2). 

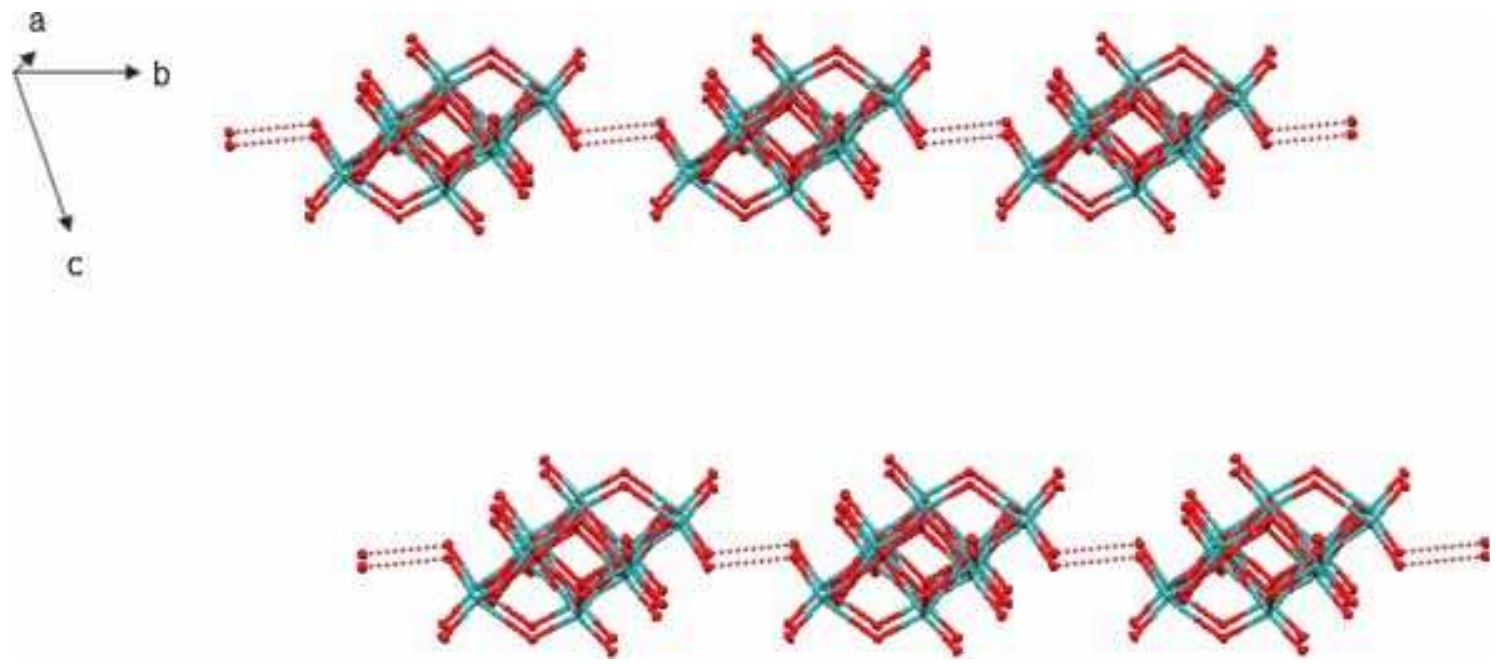

Figure 2. A representation of the one-dimensional double chain running parallel to the crystallographic (bc) plane. Organic molecules are omitted for clarity.

The organic moiety exhibits regular packing with face-to-face interactions between the monoprotonated cations and tolidine molecule, and between monoprotonated tolidine cations- tolidine molecule inter chain leading to a compact supramolecular framework structure to accommodate one-dimensional inorganic chains (figure 3).

The hydrogen bonding distances (table 2) between terminal $\mathrm{O}_{\mathrm{t}}$ atoms of $\mathrm{Mo}_{8} \mathrm{O}_{26}$ anion and hydrogen atoms are $\mathrm{O}_{\mathrm{t}}(3)-\mathrm{H}(21 \mathrm{~B}) 1.980 \AA, \mathrm{O}_{\mathrm{t}}(5)-\mathrm{H}(21 \mathrm{~A}) 2.030$ $\AA, \mathrm{O}_{\mathrm{t}}(2)-\mathrm{H}(21 \mathrm{~B}) 2.460 \AA, \mathrm{O}_{\mathrm{t}}(4)-\mathrm{H}(10 \mathrm{~A}) 2.220 \AA$ and $\mathrm{O}_{\mathrm{t}}(6)-\mathrm{H}(20 \mathrm{~A}) 2.400 \AA$. The $\mathrm{H}(30 \mathrm{~A})$ - tolidine molecules lie on the bridging oxygen $\mathrm{O} \mu$ of $\mathrm{Mo}_{8} \mathrm{O}_{26}$, the hydrogen bonding distance is $2.000 \AA$ for $\mathrm{O} \mu$ (8)- $\mathrm{H}(30 \mathrm{~A})$ (figure 4).

\subsection{IR spectral characterization}

The IR spectrum of the title compound $\mathbf{1}$ in figure S1 (Supplementary Information) shows characteristic vibrational features similar to the known $\beta$ - $\left[\mathrm{Mo}_{8} \mathrm{O}_{26}\right]^{4-}$ anions. $^{21}$

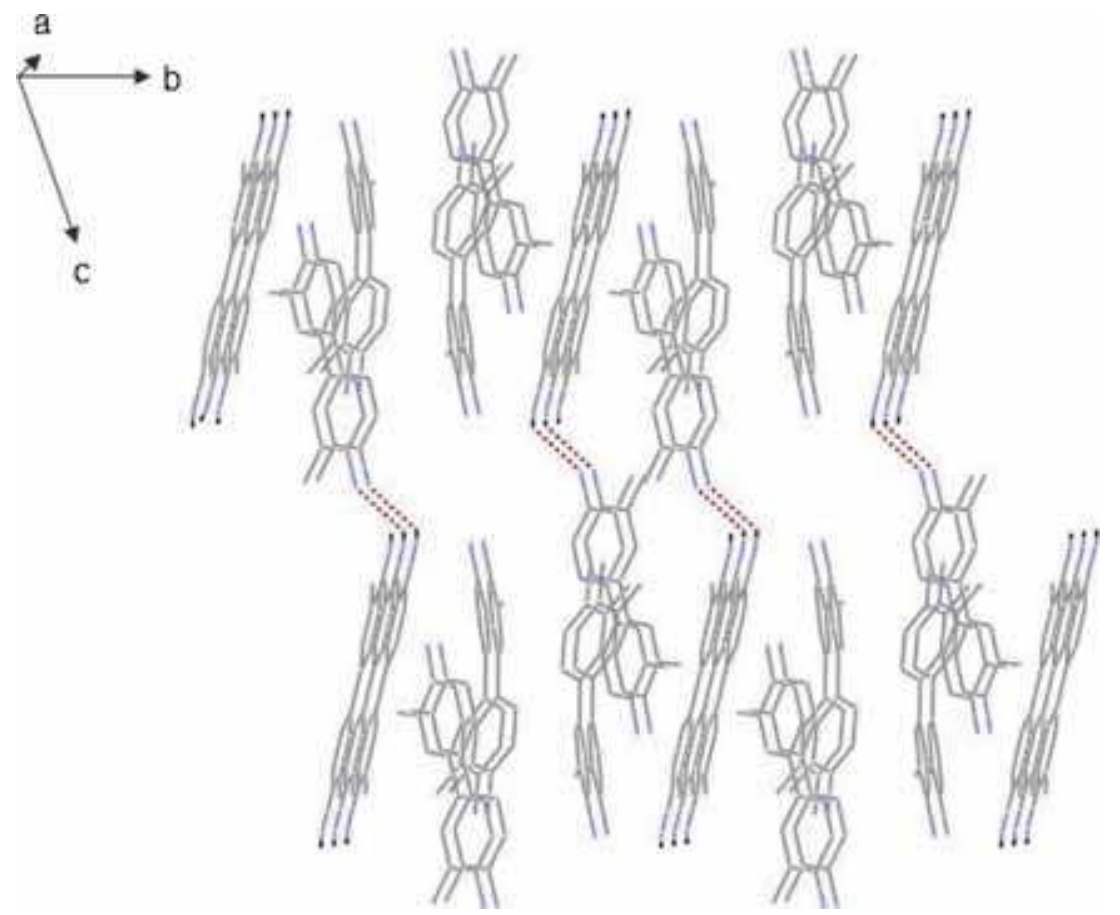

Figure 3. Packing map of organic molecules. Inorganic molecules are omitted for clarity. 
Table 2. Hydrogen-bond geometry, distances and angles $\left(\AA,^{\circ}\right)$

\begin{tabular}{|c|c|c|c|c|}
\hline$D-\mathrm{H} \cdots A$ & $D-\mathrm{H}$ & $\mathrm{H} \cdots A$ & $D \cdots A$ & $D-\mathrm{H} \cdots A$ \\
\hline N101-H10A $\cdots$ O $^{\mathrm{i}}$ & 0.88 & 2.22 & $3.060(3)$ & 159 \\
\hline $\mathrm{N} 101-\mathrm{H} 10 \mathrm{~B} \cdots \mathrm{N} 301^{\mathrm{i}}$ & 0.88 & 2.56 & $2.899(3)$ & 104 \\
\hline $\mathrm{N} 115-\mathrm{H} 11 \mathrm{~A} \cdots \mathrm{O} 12^{\mathrm{ii}}$ & 0.88 & 2.55 & $3.327(3)$ & 147 \\
\hline N201-H20A $\cdots$ O6 $^{\mathrm{iii}}$ & 0.88 & 2.40 & $3.035(3)$ & 130 \\
\hline $\mathrm{N} 201-\mathrm{H} 20 \mathrm{~B} \cdots \mathrm{O} 11^{\mathrm{iv}}$ & 0.88 & 2.53 & $3.388(3)$ & 166 \\
\hline $\mathrm{N} 215-\mathrm{H} 21 \mathrm{~A} \cdots \mathrm{O}^{\mathrm{v}}$ & 0.91 & 2.03 & $2.888(3)$ & 158 \\
\hline $\mathrm{N} 215-\mathrm{H} 21 \mathrm{~B} \cdots \mathrm{O} 2^{\mathrm{v}}$ & 0.91 & 2.46 & $2.785(3)$ & 101 \\
\hline $\mathrm{N} 215-\mathrm{H} 21 \mathrm{~B} \cdots \mathrm{O} 3^{\mathrm{v}}$ & 0.91 & 1.98 & $2.878(3)$ & 171 \\
\hline $\mathrm{N} 215-\mathrm{H} 21 \mathrm{C} \cdot \mathrm{O} 1^{\mathrm{vi}}$ & 0.91 & 2.07 & $2.978(3)$ & 173 \\
\hline N301-H30A $\cdots \mathrm{O}^{\text {iv }}$ & 0.88 & 2.59 & $3.024(3)$ & 112 \\
\hline $\mathrm{N} 301-\mathrm{H} 30 \mathrm{~A} \cdots \mathrm{O}^{\mathrm{iv}}$ & 0.88 & 2.00 & $2.786(3)$ & 148 \\
\hline $\mathrm{N} 301-\mathrm{H} 30 \mathrm{~B} \cdots \mathrm{N} 101^{\mathrm{i}}$ & 0.88 & 2.30 & $2.899(3)$ & 126 \\
\hline $\mathrm{C} 108-\mathrm{H} 10 \mathrm{D} \cdots \mathrm{O} 2^{\mathrm{vii}}$ & 0.98 & 2.45 & $3.382(3)$ & 158 \\
\hline $\mathrm{C} 108-\mathrm{H} 10 \mathrm{E} \cdots \mathrm{O}^{\mathrm{iii}}$ & 0.98 & 2.56 & $3.396(3)$ & 144 \\
\hline
\end{tabular}

Symmetry codes: (i) $-x+2,-y+1,-z$; (ii) $-x+1,-y+1,-z+1$; (iii) $-x+1,-y+1,-z$; (iv) $x+1, y, z$; (v) $x, y, z+1$; (vi) $-x+1,-y,-z+1$; (vii) $x, y+1, z$.
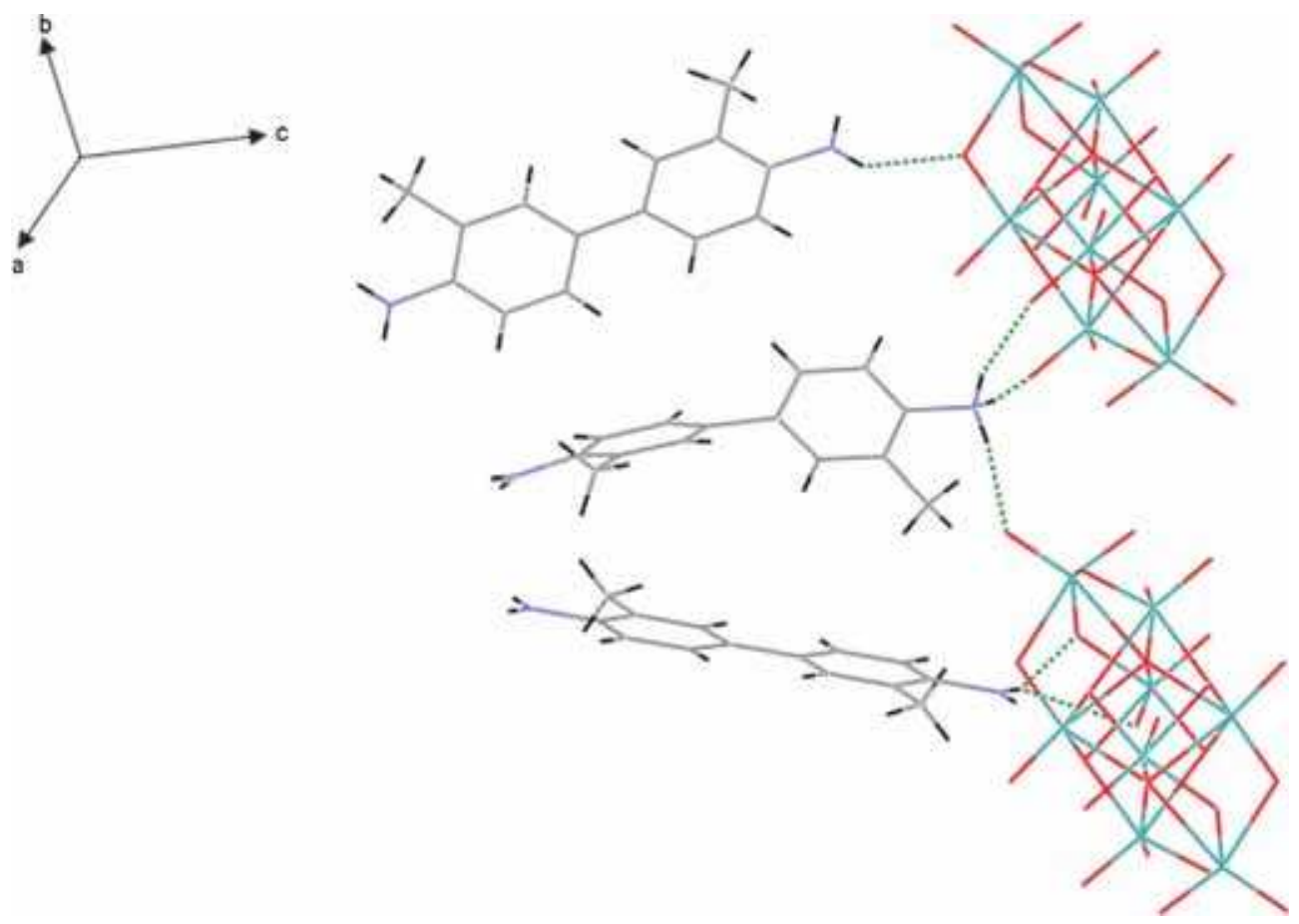

Figure 4. A view showing the weak interaction of $\mathrm{N}-\mathrm{H}-\mathrm{O}$ occurring between organic cation and inorganic anion.

The stretching vibrations at 954.1 and $713.6 \mathrm{~cm}^{-1}$ are attributed to $v_{\text {as }}(\mathrm{Mo}-\mathrm{Ot})$ and $v_{\text {as }}(\mathrm{Mo}-\mathrm{O}-\mathrm{Mo})$, respectively, and other peaks falling in the range of 898.8$759.9 \mathrm{~cm}^{-1}$ are attributed to other $v_{\text {as }}(\mathrm{Mo}-\mathrm{O})$. Further, the presence of organic group is suggested by the occurrence of a series of vibrational bands at 1624, 1492.8 and $1259.4 \mathrm{~cm}^{-1}$ resulting from the tolidine ligand.

\subsection{NMR spectroscopy}

The spectrum (figure S2) showed three different signals assigned to aromatic protons, azote protons and methyl protons. A multiplet signal between 7.25-6.82 ppm is assigned to aromatic protons. A broad peak at $4.1 \mathrm{ppm}$ is due to $\mathrm{NH}_{2}$ and $\mathrm{NH}_{3}^{+}$protons groups. $\mathrm{A}$ 
singlet corresponding to methyl protons is observed at $2.15 \mathrm{ppm}$.

\section{$3.4 \quad U V$-Vis spectroscopy}

Figure $\mathrm{S} 3$ shows the UV-Vis absorption spectrum of 1. The electronic transition at $300 \mathrm{~nm}$ in $\beta-\left[\mathrm{Mo}_{8} \mathrm{O}_{26}\right]^{4-}$ was assigned to a $\mathrm{L} \rightarrow \mathrm{M}$ charge-transfer transition from the oxygen $\pi$-type HOMO to the molybdenum $\pi$-type LUMO. Detailed molecular orbital levels and representations for the hexamolybdate and other typical polyoxometalates have been described by Poblet et al. ${ }^{22}$

\subsection{Cyclic voltammetric data}

The voltammetric behaviour of compound 1 was carried out in $\mathrm{LiClO}_{4}$ 0.1M/DMSO solution at different scan rates. As shown in figure $\mathrm{S} 4$, the cyclic voltammogram in a potential range of $800 \mathrm{mV}$ to $200 \mathrm{mV}$ exhibits two reversible redox peaks I and II and $\mathrm{E}_{1 / 2}=\left(\mathrm{E}_{\mathrm{pa}}+\mathrm{E}_{\mathrm{pc}}\right) / 2$ are $+608.5 \mathrm{mV}$ and $+439.5 \mathrm{mV}$, respectively. They correspond to one-electron redox processes of $\mathrm{Mo}^{23}$ and are ascribed to the redox reaction of the $\beta-\left[\mathrm{Mo}_{8} \mathrm{O}_{26}\right]^{4-}$ anions. The two reduction processes can be assigned to $\mathrm{Mo}^{\mathrm{VI}} \rightarrow \mathrm{Mo}^{\mathrm{V}}$ and $\mathrm{Mo}^{\mathrm{V}} \rightarrow \mathrm{Mo}^{\mathrm{IV}} \cdot{ }^{24}$ With increasing of scan rates, the peak potential changes gradually with the scan rate from $20 \mathrm{mV} / \mathrm{s}$ to $400 \mathrm{mV} / \mathrm{s}$ : the cathodic peak potential shifts in the negative direction and the corresponding anodic peak potential shifts in the positive direction. Besides, the peak-to-peak separation between the corresponding peaks increases. The scan rate dependence of the anodic and cathodic peak current showed a linear increase in the peak currents as a function of the scan rate confirmed a non-diffusional surface-controlled redox process.

\section{Conclusion}

A new octamolybdate $\left(\mathrm{C}_{14} \mathrm{H}_{16} \mathrm{~N}_{2}\right)_{3}\left(\mathrm{C}_{14} \mathrm{H}_{17} \mathrm{~N}_{2}\right)_{2}\left[\mathrm{Mo}_{8}\right.$ $\mathrm{O}_{26}$ ] (1) has been synthesized by hydrothermal method and its crystallographic structure determined by $\mathrm{X}$ ray single-crystal diffraction. This structure consists of $\beta$-octamolybdate $\left[\beta-\mathrm{Mo}_{8} \mathrm{O}_{26}\right]^{4-}$ anions, tolidine molecules, monoprotonated and diprotonated tolidine cations. One tolidine molecule and a $\beta-\mathrm{Mo}_{8} \mathrm{O}_{26}$ polyanion species lie across crystallographic inversion centre while the two tolidine molecules occupy general sites. The cyclic voltammetry of compound $\mathbf{1}$ presents two reversible redox peaks which are assigned to redox reactions of molybdenum.

\section{Supplementary Information}

IR, ${ }^{1} \mathrm{H}$ NMR, UV-Vis spectra and cyclic voltammetric data are available at www.ias.ac.in/chemsci.

\section{Acknowledgements}

The authors thank Roisnel Thierry, Sciences Chimiques de Rennes (UMR CNRS 6226) University Rennes 1, France, for providing diffraction facilities.

\section{References}

1. Mizuno N and Misono M 1998 Chem. Rev. 98199

2. Rhule J T, Hill C L, Jude D A and Schinazi R F 1998 Chem. Rev. 98327

3. Katsoulis D E 1998 Chem. Rev. 98359

4. Pope M T 1983 In Heteropoly and Isopoly Oxometalates (New York: Springer)

5. (a) Coronado E, Galan-Mascaros J R, Gimenez-Saiz C and Gomez-Garcia C J 1993 Adv. Mater. 4 283; (b) Casan-Pastor N and Baker L C W 1992 J. Am. Chem. Soc. 114 10384; (c) Yamase T 1993 Mol. Eng. 3241

6. (a) McCarron III E M and Harlow I R L $1983 \mathrm{~J}$. Am. Chem. Soc. 105 6179; (b) Modec B, Brenčič J V and Zubieta J 2003 Inorg. Chem. Commun. 6506

7. Xi R, Wang B, Isobe K, Nishioka T, Toriumi $\mathrm{K}$ and Ozawa Y 1994 Inorg. Chem. 33833

8. (a) Fuchs J and Hartl H 1976 Angew. Chem. Int. Ed. Engl. 15 375; (b) Day V W, Fredrich M F, Klemperer W G and Shum W J 1977 J. Am. Chem. Soc. 99 952; (c) Hsieh T C, Shaikh S N and Zubieta J 1987 Inorg. Chem. 264079

9. (a) Lindqvist I 1950 Ark. Kemi. 2 349; (b) Atovmyan L O and Krasochka O N 1972 Zh. Strukt Khim. 13 342; (c) Vivier H, Bernard J and Djomaa H 1977 Rev. Chim. Miner. 14 584; (d) Roman P, Jaud J, Galy J 1981 Z. Kristallogr. 154 59; (e) Weakley T J R 1982 Polyhedron 1 17; (f) Hountas A and Filippakis S E 1982 Cryst. Struct. Commun. 11 1087; (g) Kroenke W J, Fackler Jr J P and Mazany A M 1983 Inorg. Chem. 22 2412; (h) Piggott B, Wong S F, Hurshouse M B and Short R L 1988 Polyhedron 7 2605; (i) Fitzroy M D, Fallon G D and Murray K S 1989 Inorg. Chim. Acta. 157 187; (j) Sun C, Wang E, Xiao D, An H and Xu L 2005 J. Mol. Struct. 741 149; (k) Zebiri I, Bencharif L, Direm A, Bencharif M and Benali-Cherif N 2008 Acta Cryst. Sect. E64 m474

10. Wangm C M, Zeng Q X, Zhang J and Yang GY 2005 Z. Anorg. Allg. Chem. 631838

11. Yang W, Lu C and Zhuang H 2002 J. Chem. Soc. Dalton Trans. 2879

12. Niven M L, Cruywagen J J and Heyns J B B $1991 \mathrm{~J}$. Chem. Soc. Dalton Trans. 2007

13. Hagrman D, Zubieta C, Rose D J, Zubieta J and Haushalter R C 1997 Angew. Chem. Int. Ed. Engl. 36 873

14. Masters A F, Ghellu S F, Brownlee R T, O'Connor M J and Wedd A G 1980 Inorg. Chem. 193866

15. Pope M T 1991 Prog. Inorg. Chem. 30181 
16. Rarig Jr. R S and Zubieta J 2001 Inorg. Chim. Acta. 312 188

17. Xu J Q, Wang R Z, Yang G Y, Xing Y H, Li D M, Bu W M, Ye L, Fan Y G, Yang G D, Xing Y, Lin Y H and Jia H Q 1999 Chem. Commun. 983

18. Hagrman D, Hagrman P and Zubieta J 2000 Inorg. Chim. Acta. 212300

19. Hagrman P J and Zubieta J 1999 Angew. Chem. Int. Ed. Engl. 382638

20. Sheldrick G M 2008 Acta Cryst. A64 112
21. (a) Roman P, Gutirrez-Zorrilla J M , Esteban-Calderon C, Martinez-Ripoll M and Garcia-Blanco S 1985 Polyhedron. 4 1043; (b) Duraisamy T, Ramanan A and Vittal J 1999 J. Mater. Chem. 9763

22. Poblet J M, López X and Bo C 2003 Chem. Soc. Rev. 32 297

23. Shi Z Y, Gu X J, Peng J and Chen Y H 2005 J. Solid State Chem. 1781996

24. Xiao Z, Zhu Y, Wie Y and Wang Y 2006 Inorg. Chem. Commun. 9400 